International Research Journal of Management, IT \& Social Sciences
Available online at https://sloap.org/journals/index.php/irjmis/
Vol. 7 No. 1, January 2020, pages: 162-168
ISSN: 2395-7492
https://doi.org/10.21744/irjmis.v7n1.838

\title{
Semantic Complications in the War on Terror Discourse and Manipulation of Language by State and Non-State Actors
}

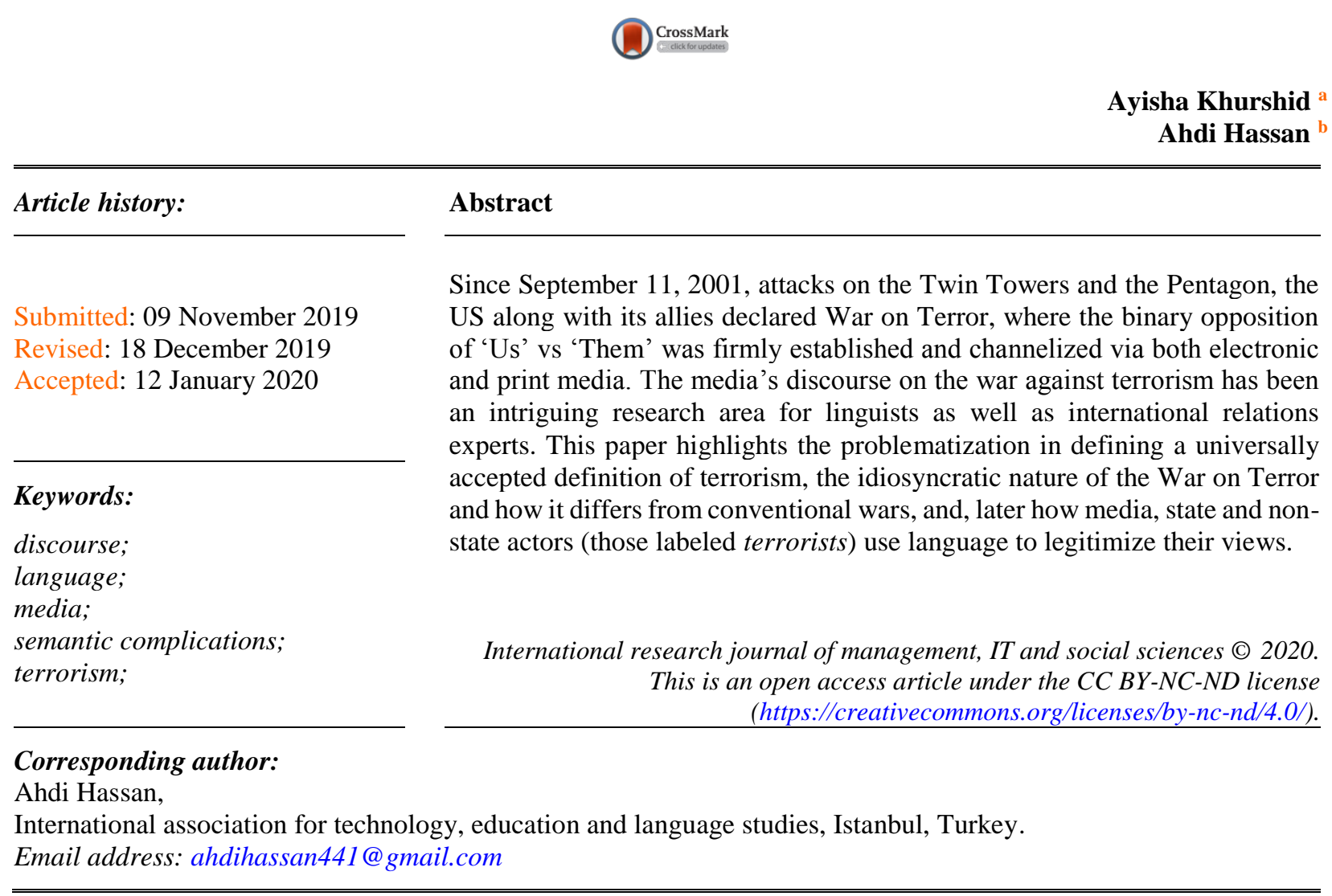

COMSATS University, Islamabad, Pakistan

International association for technology, education and language studies, Istanbul, Turkey 


\section{Introduction}

Terrorism scholarship, among other things, looks at how relevant terms undergo semantic transformations (Hoffman, 1998). It also brings into mainstream discourse the problematic nature of defining terms like terrorism from a normative stance, implying that various countries have their own parameters for defining such terms. The vagueness in the semantic structure of terrorism discourse where various events are enlisted along with multiple actors, such as oppression by state actors, mass shooting by a single person, and civilian carnages, contribute to the difficulties for the researchers to study in the very domain (Lizardo, 2008). The problem in conceptualizing terrorism is evident from previous research where more than 200 different dimensional definitions exist (Matusitz, 2013; Simon, 1994; Schmid 2004b; Astawa et al., 2017; Schmid, 2011). Terrorism as an 'ism' is hard to define as there is a lack of consensus on what constitutes terrorism. The first-ever use of the root word terror from the Latin term terrier is documented in English in 1528 (Young, 2006). With the suffix 'ism' it implies the practicing and causing of terror (where terror is synonymous with frighten) and this 'ism' (both as a practice and a word) has its roots in the French Revolution of the 1790s. The significant aspect of the semantic understanding of the very ism was then related to the state actors rather than non-state actors (this aspect has drastically changed in the modern understanding of terrorism). Terrorism was considered integral to counter the anti-revolutionaries thus maintaining law and order (Hoffman, 1998). The revolutionary leader Maximilien Robespierre articulated his justification of the use of terror in the following words;

So, the use of terror was seen as a form of justice tied with democracy. But during the French revolution, it changed its meaning to what is now termed state oppression implying abuse of authority and power. The revolutionaries executed 40,000 people by guillotine on the charges of anti-revolutionaries and thus deemed them as traitors (Hoffman, 1998). It is recalled in history as the reign of terror. It is also pertinent to mention that in this very epoch the term terrorist was first employed by Edmund Burke in 1795 in his "Letters on a Regicide Peace" (Thorup, 2010). Due to the heterogeneity of the contexts in which the word terrorism is used, the consensus-building around its semantic side is problematic (Ramsay, 2015). There are many arguments put forth to elaborate on the problematic nature of having a universally accepted dimension of terrorism ranging from political, legal and cultural dimensions to variety in its goals, and lack of clarity on its boundaries (in the sense of nature of violence) (Schmid, 2004a). Ganor (2002), argues that an objective definition is possible and differentiates between guguerrillareilla warfare and terrorism. The key aspect which he discusses is the identification of a target i.e., if they are military personnel, it is a guerrilla attack, whereas if they are civilians, it is a terrorist attack. Such a demarcation is misleading as in the case of Pakistan, AlQaeda's major target is the military and the motive is largely based upon revenge. According to the above definition, Al-Qaeda as a group will fall under guerrilla and the bombings against the military will not be counted as an act of terrorism. Terror is nothing else than immediate justice, severe and inflexible; it is, therefore, an outflow of virtue; it is not much to a specific principle than a consequence of the general principle of democracy applied to the most pressing needs of the homeland (Schmid, 2011).

Similarly, the specific approach of defining terrorism (Golder \& Wiliams, 2004) is also problematic as it categorizes specific activities like hijacking, assassination, and suicide bombing, etc as an act of terrorism. The debate of whether mass shooting in the US is an act of terrorism is gaining momentum while previously it was not seen as domestic terrorism per se, but now people are demanding it to be enlisted under acts of terrorism (Umontuen, 2018). Similarly, not all countries classify assassination as an act of terrorism and some scholars distinguish between criminal and terrorist assassination (Rapaport, 1971). In terms of the general approach towards defining terrorism (Greene, 2017), "intention or motivation" (Golder \& Wiliams, 2004), are taken into consideration. The social or political motives of the perpetrators, at times earn for them different labels: freedom fighters may or may not be termed terrorists depending upon the cultural, and geographical context. Due to such complexity in what constitutes terrorism, there is still no universally accepted legal definition. Although the United Nations' Security Council proposed one in 2004, it is nonbinding and has no legal authority.

As there is no consensus on the universality of what constitutes terrorism, and my research's focus is on the US media, it is essential to define terrorism according to a specific country's institutional and legal context. Under the United States Law Code, terrorism is defined as "premeditated, politically motivated violence perpetrated against noncombatant targets by subnational groups or clandestine agents" (US State Department, 2005). Further, it is defined under the Code of Federal Regulation as "the unlawful use of force and violence against persons or property to intimidate or coerce a government, the civilian population, or any segment thereof, in furtherance of political or social objectives" (2005). The Federal Bureau of Investigation further differentiates between domestic and international terrorism, where the former implies violent/dangerous acts intended or committed on the US soil and the latter outside the territorial jurisdiction of the USA (Golder \& Wiliams, 2004). As there is no universal legal definition of terrorism,

Khurshid, A., \& Hassan, A. (2020). Semantic complications in the war on terror discourse and manipulation of language by state and non-state actors. International Research Journal of Management, IT and Social Sciences, 7(1), 162-168. https://doi.org/10.21744/irjmis.v7n1.838 
the scholarship on terrorism takes into consideration four domains of discourse, i.e., academia, the state, the public sphere and mass media, and terrorists and their supporters' arguments (Schmid, 1992). But these four domains at times overlap where the mass media debate may be positioned in the light of the state's policies and statements. Various studies have been conducted to decipher how academics define and reach consensus in defining the term terrorism (Weinberg et al., 2004; Schmid, 1992 and 2004). Schmid's 22 distinctive elements in defining terrorism have been employed by various studies along with modifications to scrutinize its consensual blocks. But Schmid's definition lacks the territorial dimension. Pinos \& Radil (2018), argue that the territorial claim is the major motivational force where the non-state actors want to exert their influence via spreading terrorism.

\section{Materials and Methods}

This is a conceptual paper based upon the reviews of articles published on identifying semantic complications in defining the term terrorism from its etymology to present-day usage. The paper then relates terrorism in the light of US law and relates it to the war on terror. The final strand of this paper then comments upon how state and non-state actors have been using language in the backdrop of terrorism discourse to disseminate their ideologies. It also comments upon the research gap where still a lot of studies are required to study how non-state actors especially terrorists declared organizations use media to manipulate their target audience.

\section{Results and Discussions}

The state's discourse on terrorism positions the state as the most powerful actor who has the power to define and create truths related to terrorist acts (Martini, 2016). The state has the power to define and build the discourse on legitimizing state policies to counter-terrorism (Hülsse \& Spencer, 2008). The scenario becomes more complicated when the state itself becomes an agent of terrorism thereby sponsoring terrorist organizations or directly getting involved in spreading terror. On the contrary to state actors, terrorists have less control over the terrorism discourse (Martini, 2016) as the government officials shape the events. Scant studies have been carried out to scrutinize this side of the narrative, i.e. as to how terrorists channelize their views, use media to gain support and build their own discourse of legitimization of violent action. Terrorists use discursive strategies to build their identities via websites (Rothenberger et al., 2018), shape narratives to suit their goals (Pokalova, 2018) and justify their actions (Rothenberger \& Kotarac, 2016).

There have also been attempts to study how the general public understands terrorism. Huff \& Kertzer (2018), using the survey method compiled a questionnaire based on the aspect of the use of "tactics, target, location, casualties, actor description, actor type and motivation" (p.67). Their findings suggest that there may be a significant connection between public opinion and the media's framing of violent events.

The density in defining terrorism is also much reflected when we research the phases in the history of modern terrorism. Rapoport (2016), an expert in the domain of terrorism scholarship, divides the history of terrorism into four waves i.e., Anarchist, Nationalist, Marxist and Religious. In his view, the first wave emerged in the 1880s in Russia by a group named Narodnaya Vola and it continued till the early $20^{\text {th }}$ century. The next one gyrated around anticolonialism from the 1920s until the 1960s, and the third one from the 1960s lasted until the end of the $20^{\text {th }}$ century. The last one, the religious tide, began in late the 1970s and continues to date (Parker \& Sitter, 2016). Rapoport also predicts that the present tide will be replaced by a new one by 2025. But Parker and Sitter (2016) criticize the wave metaphor and use the strained metaphor to present their own version of four waves; "Socialist, Nationalist, Religious and Exclusionist" (Parker \& Sitter, 2016). They think that terrorists learn and modify their strategies by taking aid from their predecessors. Like strain, they have the tendency to spread; when one tactic/strategy is successful in one part of the world, it is more likely to be used by other terrorist groups.

\section{Defining the war on terror and its idiosyncratic nature}

Terrorism is what we call the violence of the weak, and we condemn it; war is what we call the violence of the strong, and we glorify it (Harris, 1986). Despite the fact that terrorism remains a non-consensual term across various disciplines, there is a shared agreement upon what constitutes the War on Terror. The War on Terror refers to the military campaign launched by the US along with its allies against terrorism after the $9 / 11$ attacks (Katz, 2012). Other terms such as Global War on Terror (GWOT) (Smith \& Zeigler, 2017) and Global Struggle Against Violent Extremism (GSAVE) have been used, but War on Terror remains popular. The phrase was first employed by the Bush administration in the aftermath of September 11, 2001 attacks on the Twin Towers. Our enemy is a radical network of 
terrorists, and every government that supports them. Our war on terror begins with al Qaeda, but it does not end there. It will not end until every terrorist group of global reach has been found, stopped and defeated (Bush, 2001). When the term is first used, the antagonists in the narrative are non-state organizations and governments around the world who support terrorism. But what remains unclear is "every terrorist group" and who it refers to, what are the normative issues in it and how to reach a consensus over group identification.

The 9/11 attacks were termed terrorist attacks by the US media due to (i) the tactics employed, (ii) civilian targets, (iii) non-state actors' involvement, (iv) developing fear, (v) immediacy of the distance and (vi) political goals. It is also pertinent to mention that the 9/11 attacks mark the historical shift in the wave/strain of terrorism (as explained in the previous section) to religion (Smith \& Zeigler, 2017). Al-Qaeda's status as a terrorist group was designated by the US administration in the aftermath of the 2001 attacks. But had the organization always been a terrorist group is an interesting question. The organization was formed during the Afghan-Soviet War in the 1980s and at that particular time, its role was to provide logistics to those Muslims fighting against the Soviet (2018). The concept of 'Jihad' (not to be confused with multiple variations in its meaning in Arabic language and Islamic Holy Book), which is now equated with Holy War (see Encyclopaedia Britannica), in those days was seen as a method to defeat the Soviet Army and the United States played a crucial role in promoting this concept along this line. The word appeared in an ABC song in Afghan textbooks designed by the University of Nebraska to turn people towards it, "Jihad is an obligation. My mom went on jihad. My brother gave water to the Mujahidin” (Gul, 2010; Stephens \& Ottaway, 2002). The books mentioned were filled with the images of guns, rifles, soldiers, and highlighted Mujahedeen's glory (the word implies militias fighting in the name of Islam). But this narrative dramatically changed in the aftermath of the 9/11 attacks. Again the USAID injected dollars to revise the above-designed books to remove the violent contents like guns, bullets and also the concept of Jihad. This change in strategy also highlights the change in the semantic evaluation of such terms. The term jihad is no longer used in the positive sense of a strategy to win the battle as was the case in the Afghan-Soviet war.

But this war differs significantly from the conventional wars in many ways. Beginning with the name itself, the metaphor was employed for domestic political objectives to vest more power into the Presidency and to present the war as the only solution to defend the US public (Lakoff, 2006). The same metaphor has been used to defend the invasion of Iraq. Though on one level the War on Terror is a conceptual metaphor it does refer to a military campaign. The problem arises with respect to terror, as to how real wars (conventional wars) can be waged against an emotional state. So terror is an embodiment of an existential threat posed by multiple enemies. But unlike conventional wars, there is no clear identification in terms of the geographical, national and ethnic dimensions of the enemies' identities. Conventional war has been fought against certain countries but in terms of the Afghanistan and Iraq wars, although the territories were bombed, the war did not involve uniformed soldiers. Conventional wars have a beginning and an end, yet the War on Terror does not have a specific timeline for its end (Raz, 2006). This implies that the War on Terror, unlike conventional war, lacks a battlefield (Sitaraman, 2009), thus the war metaphor should no longer be employed (Hass, 2006). In a similar way, Lakoff (2006), argues that the War on Terror metaphor is problematic and progressives should avoid it; as it is oriented towards creating fear rather than pointing to terrorists. Despite much chagrin over the usage of the War on Terror metaphor by linguists and social scientists, it is still widely employed by politicians around the world to legitimize their military campaigns both on the domestic and the international levels.

\section{Media and the war on terror: the interplay of language by state and non-state actors}

The relationship between terrorism and media can be studied on three levels; "terrorists and government", "terrorists and media" and "government and media" (Crelinsten, 1989). All three actors use and manipulate language to suit their purpose. When the media are used by the governments especially in the case of the War on Terror, not only the government policies are articulated and made legitimate, but also the portrayal of the enemies' identities is built around the discourse of 'others', where at times they are dehumanized via animal metaphors like rat, hunt, and snare, etc. (Steuter \& Wills, 2009) and object metaphors like elements. Such dehumanizing strategies are used to depict enemies as monsters not worthy of humane treatment (Maiese, 2003). The media are not only used by the governments to channelize their views and to shape public opinion but recently the terrorist organizations have also been making use of media to disseminate their views. They also use the media for propaganda to achieve their goals (Wilkinson \& Gunnell, 2000) and spread terror (Weimann, 2005). Rothenberger et al. (2018), have employed Critical Discourse Analysis to study the discursive strategies used by 'terrorist groups' to build their identities by using websites to communicate. Similar methods have been employed to scrutinize how magazines produced by Al-Qaeda and the Islamic State (IS) position their identities. The results indicate differences in the policy goals where the former is

Khurshid, A., \& Hassan, A. (2020). Semantic complications in the war on terror discourse and manipulation of language by state and non-state actors. International Research Journal of Management, IT and Social Sciences, 7(1), 162-168. https://doi.org/10.21744/irjmis.v7n1.838 
directed towards the outward change i.e. other countries, whereas the formers' aim is to declare the Caliphate (Novenario, 2016).

When it comes to media as an actor, Schudson (2011) gives three main reasons which compel American journalists to abandon a "neutral stance". "In moments of tragedy, journalists assume a pastoral role" (Schudson, 2002) means that while covering tragic stories, an element of grief is added into the script and an atmosphere of gloom is created. Then, in moments of "public danger" (ibid.) journalists abandon an objective approach. By "public danger" Schudson means danger posed by "hurricanes' and 'terrorists". The third situation arises when there are "threats to national security' (ibid.). The $9 / 11$ event provoked all these three factors, there were deaths of innocent people, there were threats to the public by terrorists, and lastly, it was a matter of national security. Under normal circumstances, journalists would have covered the event by detaching themselves from the public, but it was a matter of war, so journalists had to abandon objectivity. Soon after the collapse of the twin towers "the media hunt for the villains had begun" (Huffington, 2001). President Bush's speeches were hugely backed up by the US media. The rhetoric had once again begun, "Us vs. them," (Clift, 2010) "peace lovers vs. terrorist," "democracy vs. tyranny" etc. Lewis (2014), explicates how the Bush-Cheney administration had built up their discourse on key terms like 'freedom' and 'democracy'.

US media backed the Bush Doctrine (the foreign policy principles, majorly based upon unilateralism and preemptive strikes, of President Georg W. Bush) but what came out as a negative-strand was the stereotyping of Arabs and Muslims as mere agents of terrorism. The possible threat in the choice of lexemes in the wake of 9/11 was hinted by Clark, where he speculates the threat of the development of xenophobia, he is of the view that "the collateral damage of building a culture of war is xenophobia and paranoia, much of it directed at our own citizens" (Clark, 2002). The question arises of how US media should have acted. Surveys show that the events of 9/11 raised the interest of Americans in international affairs and the public did not want traditional current affairs programs, so the media responded to their concerns and catered to their feelings (Gorman \& McLean, 2009). There has been scant literature on the coverage of domestic terrorism in the context of the US prior to 9/11 (Chermak \& Gruenewald, 2006). But since then there has been a significant rise in the coverage of domestic level terrorist acts. Apart from the US government and media houses' backing of the US domestic and foreign policies in the wake of the War on Terror, there is a whole other spectrum pertaining to the coverage of terrorist incidents in foreign countries. In the case of the New York Times, terrorist incidents in some countries are statistically given more status conferral (implying that some incidents are singled out and given more prominence) than other countries; like terrorist incidents in Pakistan and Saudi Arabia are covered more than those in India or Iraq (Beckman, 2016). Such results are not without bias as a country's alliance with the US, its location, and political orientation in defining terrorism may affect the results (ibid.). Similarly, the coverage of terrorist attacks is also influenced by the religious orientation of the perpetrators; if they are Muslims they are likely to receive much more status conferral (Kentish, 2017).

\section{Conclusion}

In this paper, I tried to review the theoretical problems posed by vagueness and complexities in defining terms like terrorism and war on terror which are conspicuously used by social scientists in their research. This complexity further highlights the biases and manipulation of language by majorly state and non-state actors to justify their acts and policies. Until the terms like terrorism remain vague, there would always be conflict over what to label as an act of violence and biases will continue to prevail over counter policies and strategies. Since it is a review paper, there needs to be done extensive research over the non-state actor's use of language and how they build their discourse against state actors' via media.

\section{Conflict of interest statement}

The authors declared that they have no competing interests.

\section{Statement of authorship}

The authors have a responsibility for the conception and design of the study. The authors have approved the final article.

\section{Acknowledgments}

I am grateful to two anonymous reviewers for their valuable comments on the earlier version of this paper. 


\section{References}

Astawa, I. N., Mantra, I. B. N., \& Widiastuti, I. A. M. S. (2017). Developing communicative English language tests for tourism vocational high school students. International Journal of Social Sciences and Humanities, 1(2), 58-64. https://doi.org/10.29332/ijssh.v1n2.43

Beckman, M. (2016). "Which Countries' Terrorist Attacks Are Ignored By The U.S. Media?" five thirty eight. doi:<https://fivethirtyeight.com/features/which- countries-terrorist-attacks-are-ignored-by-the-u-s-media/>.

Bush, G. W. (2001). President Bush addresses the nation. Washington Post, 20, 2001.

Castan Pinos, J., \& M. Radil, S. (2018). The territorial contours of terrorism: A conceptual model of territory for nonstate violence. Terrorism and Political Violence, 1-20. https://doi.org/10.1080/09546553.2018.1442328

Chermak, S. M., \& Gruenewald, J. (2006). The media's coverage of domestic terrorism. Justice Quarterly, 23(4), 428461. https://doi.org/10.1080/07418820600985305

Clark, R. P. (2002). Journalism. St. Petersburg: The Poynter Institute for Media Studies, 1994. Ghiglione, Loren, ed. Improving Newswriting: The Best of the American Society of Newspaper Editors. Washington, DC: ASNE Foundation. News Reporting and Writing: With Free Brush-Up and NRW, 188.

Clift, E. (2010). Michelle Bachelet moved Chilean government from macho to maternal. Politics Daily.

Crelinsten, R. D. (1989). Terrorism and the media: Problems, solutions, and counterproblems. Political Communication, 6(4), 311-339. https://doi.org/10.1080/10584609.1989.9962881

Ganor, B. (2002). Defining terrorism: Is one man's terrorist another man's freedom fighter?. Police Practice and Research, 3(4), 287-304. https://doi.org/10.1080/1561426022000032060

Golder, B., \& George, W. (2004). What is Terrorism-Problems of Legal Definition. UNSWLJ, 27, 270.

Gorman, L., \& McLean, D. (2009). Media and society into the 21st century: a historical introduction. John Wiley \& Sons.

Greene, A. (2017). Defining terrorism: one size fits all?. International \& Comparative Law Quarterly, 66(2), 411-440. https://doi.org/10.1017/S0020589317000070

Gul, I. (2010). The most dangerous place: Pakistan's lawless frontier. Penguin UK.

Harris, S. J. (1986). Clearing the Ground. doi:< https://www.azquotes.com/author/6311-Sydney_J_Harris>'Holy War'. In Encyclopaedia Britannica.

Hass, R. N. (2006). Drop the "War on Terrorism” Metaphor. Daily Star. doi:<https://yaleglobal.yale.edu/content/dropwar-terrorism-metaphor>.

Hoffman, B. (1998). Inside Terrorism Columbia University Press. ISBN 0.

Huff, C., \& Kertzer, J. D. (2018). How the public defines terrorism. American Journal of Political Science, 62(1), 5571. https://doi.org/10.1111/ajps.12329

Huffington, A. (2001). Governor Davis and the Failure of Power. Salon. com.

Hülsse, R., \& Spencer, A. (2008). The metaphor of terror: Terrorism studies and the constructivist turn. Security Dialogue, 39(6), 571-592. https://doi.org/10.1177\%2F0967010608098210

Katz, M. N. (2012). Leaving without losing: The war on terror after Iraq and Afghanistan. JHU Press.

Kentish, B. (2017). Terror attacks receive five times more media coverage if perpetrator is Muslim, study finds. The Independent.

Lakoff, G. (2006). Whose freedom?: the battle over America's most important idea. Farrar, Straus and Giroux.

Lewis, C. (2014). 935 Lies: The Future of Truth and the Decline of America S Moral Integrity. Public Affairs.

Lizardo, O. (2008). Defining and theorizing terrorism: A global actor-centered approach. Journal of World-Systems Research, 14(2), 91-118. https://doi.org/10.5195/jwsr.2008.341

Maiese, M. (2003). Dehumanization. Beyond Intractability. Retrieved January 20, 2006.

Martini, A. (2016). The Construction of the Discourse on" Terrorism". Politikon, 30.

Matusitz, J. (2013). Terrorism and communication. Sage.

Novenario, C. M. I. (2016). Differentiating Al Qaeda and the Islamic State through strategies publicized in Jihadist magazines. Studies in Conflict \& Terrorism, 39(11), 953-967. https://doi.org/10.1080/1057610X.2016.1151679

Parker, T., \& Sitter, N. (2016). The Four Horsemen of Terrorism: It's Not Waves, It's Strains. Terrorism and Political Violence, 28(2), 197-216.

Pokalova, E. (2018). The Al Qaeda Brand: The Strategic Use of the "Terrorist" Label. Terrorism and Political Violence, 30(3), 408-427. https://doi.org/10.1080/09546553.2016.1169175

Ramsay, G. (2015). Why terrorism can, but should not be defined. Critical Studies on Terrorism, 8(2), $211-228$. https://doi.org/10.1080/17539153.2014.988452

Rapoport, D. C. (1971). Assassination \& terrorism. Canadian Broadcasting Corporation (CBC Audio).

Khurshid, A., \& Hassan, A. (2020). Semantic complications in the war on terror discourse and manipulation of language by state and non-state actors. International Research Journal of Management, IT and Social Sciences, 7(1), 162-168. https://doi.org/10.21744/irjmis.v7n1.838 
Rapoport, D. C. (2016). It is waves, not strains. Terrorism and Political Violence, 28(2), $217-224$. https://doi.org/10.1080/09546553.2015.1112278

Raz, G. (2006). Defining the war on Terror. NPR: All things considered.

Rothenberger, L., \& Kotarac, M. (2014). The discursive construction of a religious terrorist group identity. Култура/Culture, 5(11), 91-102.

Rothenberger, L., Müller, K., \& Elmezeny, A. (2018). The discursive construction of terrorist group identity. Terrorism and Political Violence, 30(3), 428-453. https://doi.org/10.1080/09546553.2016.1180288

Schmid, A. (2004a). Framework for Conceptualizing Terrorism. Terrorism and Political Violence 16 (2), $197-221$.

Schmid, A. (2004b). Terrorism - The Definitional Problem. Case Western Reserve Journal of International Law, 36(2), 375-419.

Schmid, A. P. (1992). The response problem as a definition problem. Terrorism and Political Violence, 4(4), 7-13. https://doi.org/10.1080/09546559208427172

Schmid, A. P. (Ed.). (2011). The Routledge handbook of terrorism research. Taylor \& Francis.

Schudson, M. (2011). What's unusual about covering politics as usual. In Journalism after September 11 (pp. $70-80)$. Routledge.

Simon Jeffrey, D. (1994). The Terrorist Trap: America’s Experience with Terrorism/Jeffrey D. Simon.

Sitaraman, G. (2009). Counterinsurgency, the War on Terror, and the Laws of War. Va. L. Rev., 95, 1745.

Smith, M., \& Zeigler, S. M. (2017). Terrorism before and after 9/11-a more dangerous world?. Research \& Politics, 4(4), 2053168017739757. https://doi.org/10.1177\%2F2053168017739757

Stephens, J., \& Ottaway, D. B. (2002). From US, the ABC's of jihad. Washington Post, 23, A01.

Steuter, E., \& Wills, D. (2009). Discourses of Dehumanization: Enemy Construction and Canadian Media Complicity in the Framing of the War on Terror. Global Media Journal: Canadian Edition, 2(2).

Thorup, M. (2010). An intellectual history of terror: War, violence and the state. Routledge.

Umontuen, I. (2018). "Call School Shootings What They Really are: Acts of Domestic Terrorism." The Atlantic Voice, February 21.

Weimann, G. (2005). The theater of terror: The psychology of terrorism and the mass media. Journal of aggression, maltreatment \& trauma, 9(3-4), 379-390. https://doi.org/10.1300/J146v09n03_08

Weinberg, L., Pedahzur, A., \& Hirsch-Hoefler, S. (2004). The challenges of conceptualizing terrorism. Terrorism and Policical Violence, 16(4), 777-794. https://doi.org/10.1080/095465590899768

Wilkinson, D., \& Gunnell, D. (2000). Youth suicide trends in Australian metropolitan and non-metropolitan areas, 1988-1997. Australian \& New Zealand Journal of Psychiatry, 34(5), 822-828. https://doi.org/10.1080\%2Fj.14401614.2000.00812.x

Young, R. (2006). Defining terrorism: The evolution of terrorism as a legal concept in international law and its influence on definitions in domestic legislation. BC Int'l \& Comp. L. Rev., 29, 23. 